\title{
Pelatihan Penjualan Produk di Era Digital Melalui E-Commerce pada Penyandang Disabilitas di Kota Magelang
}

\author{
Yulida Army Nurcahya', Ayunda Putri Nilasari², Risma Wira Bharata ${ }^{3}$, Rizky \\ Puspita Dewi ${ }^{4}$ \\ 1,2,3,4Universitas Tidar \\ e-mail: 1yulidaarmy@untidar.ac.id, 2ayundaputri.nilasari@yahoo.com, \\ 3rismawirab@untidar.ac.id, ${ }^{4}$ rizkypuspita2017@gmail.com
}

\begin{abstract}
Abstrak
Menurut UU No. 8 Tahun 2016 tentang penyandang disabilitas adalah setiap orang yang mengalami keterbatasan fisik, intelektual, mental, dan/atau sensorik dalam jangka waktu lama (Presiden Republik Indonesia, 2016). Maka dari itu kami Tim Pengabdian Universitas Tidar melakukan pelatihan penjualan produk di era digital melalui e-commerce pada penyandang disabilitas Kota Magelang untuk mendorong kemandirian dan meningkatkan kemampuan penyandang disabilitas agar mengetahui peran e-commerce yang diharapkan dapat memberikan manfaat dalam penjualan produk. Penerapan e-commerce dengan baik dapat menumbuhkan jumlah keuntungan, meningkatkan jumlah pelanggan, selain itu juga berdampak positif pada perkembangan bisnis e-commerce yang menguntungkan. Metode yang kami lakukan adalah memberikan pelatihan pada saat kunjungan penyandang disabilitas Kota magelang ke Universitas Tidar pada bulan Agustus tahun 2020. Kunjungan penyandang disabilitas Kota Magelang tetap sesuai protokol kesehatan yang berlaku. Pelatihan ini digunakan untuk mendeskripsikan fenomena aktivitas pelaku usaha dalam memanfaatkan e-commerce untuk meningkatkan tenaga penjualan. Dengan adanya pandemi covid-19 yang membuat penyandang disabilitas kurang bebas bergerak maka pemanfaatan teknologi internet, peran $e$-commerce diharapkan dapat memberikan manfaat yang besar bagi penyandang disabilitas. Hasil dari pelatihan ini menunjukkan bahwa penyandang disabilitas mampu memanfaatkan e-commerce dalam meningkatkan daya saing dan penjualan.
\end{abstract}

Kata Kunci: E-commerce, Penyandang disabilitas, Promosi Produk, Penjualan Produk

\begin{abstract}
According to Law no. 8 of 2016 concerning persons with disabilities is anyone who experiences physical, intellectual, mental, and/or sensory limitations for a long time (President of the Republic of Indonesia, 2016). Therefore, our Tidar University Service Team conducts product sales training in the digital era through e-commerce for persons with disabilities in Magelang City to encourage independence and improve the ability of persons with disabilities to know the role of e-commerce which is expected to provide benefits in product sales. The implementation of e-commerce properly can grow the number of profits, increase the number of customers, but it also has a positive impact on the development of a profitable e-commerce business. The method we use is to provide training during the visit of persons with disabilities in Magelang City to


Tidar University in August 2020. The visit of persons with disabilities in Magelang City is still in accordance with the applicable health protocol. This training is used to describe the phenomenon of business actors' activities in utilizing e-commerce to increase sales force. With the covid-19 pandemic that makes people with disabilities less free to move, the use of internet technology, the role of e-commerce is expected to provide great benefits for people with disabilities. The results of this training show that people with disabilities are able to take advantage of e-commerce to increase competitiveness and sales.

Keywords: E-commerce, Persons with disabilities, Product Promotion, Product Sales

\section{Pendahuluan}

Menurut (Lee J \& Kim Y, 2018), setiap bisnis niscaya membutuhkan dan menggunakan strategi unik untuk brand dan location targeting, dan dalam pengembangan strategi harus melibatkan pengembangan dan ide inovatif serta dituangkan dalam bentuk proyek. (Apenko, 2017) mengatakan bahwa bentuk strategi pemasaran yang paling banyak digunakan saat ini adalah pemasaran digital. Menurut (Patrutiu-Baltes, 2016) dan (Tiago M T P M B \& Veríssimo J M C, 2014), pemasaran digital membuat perusahaan dapat memperoleh keuntungan besar dengan biaya lebih rendah dengan berfokus pada pelanggan. Dengan melakukan pemasaran digital perusahaan atau individu dapat mengembangkan usahanya, sehingga kegiatan pemasaran dan promosi dapat dilakukan dengan mudah.

Kemudian menurut (Ahmed Z, Su L, Rafique K, 2017), penting bagi perusahaan untuk memahami konsep pemasaran yang akan diterapkan. Pertanyaan seperti siapa yang menjual produk, kepada siapa produk tersebut dijual, dan siapa pesaing produk tersebut harus dipertimbangkan dengan cermat agar konsep pemasaran dapat diterapkan. Sehingga mereka dapat bersaing untuk pemikiran individu tentang produk, dan dapat memperkuat identitas bisnis yang mengarah pada perbaikan dalam strategi komunikasi suatu produk untuk menopang kesuksesan bisnis. Sedangkan menurut penelitian yang dilakukan oleh (Bernal-Merino, 2018), salah satu bentuk inovasi yang membantu dalam strategi pemasaran suatu produk yang dapat menguntungkan adalah e-commerce. Menurut (Kotler dan Keller, 2009) definisi pemasaran adalah sebuah proses kemasyarakatan dimana individu dan kelompok memperoleh apa yang mereka butuhkan dan inginkan dengan menciptakan, menawarkan,dan secara bebas mempertukarkan produk dan jasa yang bernilai dengan orang lain.

Menurut (Bruni A, Cassia F, 2017), suatu perusahaan dapat berhasil jika perusahaan melakukan investasi dalam pemasaran, sehingga dapat meningkatkan posisi kompetitif perusahaan dan mengukur kinerja pemasaran perusahaan. Selain itu, hal yang harus diperhatikan oleh perusahaan agar strategi pemasaran di bidang digital dapat mulai diterapkan adalah memilih cara pemasaran yang tepat, memperhatikan promosi, kualitas konten pemasaran, sasaran atau pelanggan. Namun menurut 
(Pallud J, 2014) yang terpenting adalah target atau pelanggan karena target atau pelanggan merupakan pilar pertumbuhan, kontinuitas, dan kesuksesan suatu perusahaan.

Maka salah satu strategi yang kami berikan pelatihan kepada penyandang disabilitas adalah dengan memanfaatkan e-commerce dalam mempromosikan dan menjual produk. Hal ini dikarenakan jika para penyandang disabilitas menerapkan $e$-commerce dengan baik pada strategi pemasaran produknya, maka dampak yang dapat dirasakan oleh penyandang disabilitas adalah dapat meningkatkan jumlah keuntungan, menambah jumlah pelanggan, meningkatkan daya saing dan penjualan produk serta berbagai manfaat besar lainnya. Di Indonesia sendiri, ada banyak sekali e-commerce di antaranya Shopee dan Tokopedia. Kami tim pengabdian mengenalkan kepada para penyandang disabilitas mengenai kedua e-commerce tersebut. Karena tentu saja memberikan banyak dampak untuk banyak orang baik penjual maupun konsumen.

\section{Shopee}

Shopee, sebuah perusahaan Sea pertama kali diluncurkan di Singapura pada tahun 2015, dan sejak itu memperluas jangkauannya ke Malaysia, Thailand, Taiwan, Indonesia, Vietnam, dan Filipina. Sea adalah pemimpin dalam hiburan digital, ecommerce, dan layanan keuangan digital di Asia Tenggara Raya. Misi Sea adalah untuk memperbaiki kehidupan konsumen dan bisnis kecil dengan teknologi, dan terdaftar di NYSE dengan simbol SE. Shopee menciptakan kemudahan bagi Asia Tenggara dan merupakan platform e-commerce terkemuka di Asia Tenggara dan Taiwan. Ini adalah platform yang disesuaikan untuk wilayah tersebut, memberi pelanggan pengalaman belanja online yang mudah, aman, dan cepat melalui pembayaran yang kuat dan dukungan logistik. Shopee bertujuan untuk terus meningkatkan platformnya dan menjadi tujuan e-commerce pilihan di kawasan ini. Shopee memiliki beragam pilihan kategori produk mulai dari elektronik konsumen hingga rumah \& tempat tinggal, kesehatan \& kecantikan, bayi \& mainan, mode, dan peralatan kebugaran.

\section{Tokopedia}

Marketplace $\mathrm{C} 2 \mathrm{C}$ terbesar di Indonesia dan situs e-commerce terbesar kedua, Tokopedia diperkirakan memiliki 46 juta kunjungan setiap bulan. Pada Agustus 2017, Alibaba berinvestasi di Tokopedia, dengan nilai Tokopedia lebih dari US \$ 1 miliar. Dua perusahaan e-commerce terbesar di Indonesia, Lazada dan Tokopedia, keduanya didukung oleh perusahaan internet terbesar di China, Alibaba Group. Tokopedia didirikan pada tahun 2009 dan mengukuhkan dirinya sebagai pesaing utama Lazada ketika menerima US \$ 100 juta dari dana modal ventura SoftBank Capital dan Sequoia. Laporan media pada pertengahan 2016, mengklaim Tokopedia telah memfasilitasi rata-rata 16,5 juta transaksi bulanan dari 1 juta penjual beroperasi pada platformnya. Bisnis dapat menjual melalui pasar Tokopedia atau sebagai toko individu di dalam situs, dan sebagian besar kategori berisi produk impor. 


\section{Metode}

Metode merupakan suatu sistem untuk mencapai tujuan tertentu (Sugiyono, 2016) Pelaksanaan program pengabdian kepada masyarakat ini dilakukan dengan menggunakan metode parsitipatif, penyuluhan, pendampingan dan pelatihan di lokasi Universitas Tidar, namun sebelum melakukan pengabdian ini kami tim pengabdian yang terdiri dari 3 dosen dan 2 mahasiswa melakukan kerja sama dengan instansi dinas sosial Kota Magelang. Dalam keadaan pandemi covid-19 maka kami tim pengabdian Universitas Tidar memberikan pelatihan kepada penyandang disabilitas pada tanggal 11 agustus 2020 mulai pukul 08.00 - 12.00 bertempat digedung Fakultas Ekonomi Universitas Tidar dengan pendampingan dari Dinas Sosial Kota Magelang. Kami sangat berterimakasih sekali dengan adanya dukungan dari dinas sosial Kota Magelang karena para penyandang disabilitas diberikan sarana transportasi untuk menuju ke Universitas Tidar. Tahapan pertama yang kami lakukan pada saat pelatihan adalah memberikan motivasi kepada para penyandang disabilitas bahwasannya penyandang disabilitas adalah anugerah terindah yang diberikan tuhan dan jangan pernah menyerah karena kekurangan tersebut. Yang kedua kami mengajarkan keterampilan dari plastik bekas menjadi hiasan yang bisa menjadi produk yang bisa dijual. Yang ketiga memberikan pengenalan bagaimana produk dari plastik bekas yang bisa menjadi hiasan dapat dipasarkan melalui e-commerce. Setelah diberikan pelatihan kami melakukan pendampingan melalui whatsApp group untuk memantau sejauh mana progress yang sudah dilakukan oleh peserta.

\section{Hasil dan Pembahasan}

Pelaksanaan pengabdian kepada penyandang disabilitas dengan melibatkan Dinas Sosial Kota Magelang ini terhadap suatu permasalahan yang dihadapi mengenai penjualan yang dilakukan secara tradisional kurang efektif untuk memperkenalkan produk kepada masyarakat. Selain itu kemampuan dalam mempromosikan barang, serta pemanfaatan barang bekas yang tidak terpakai dapat menghasilkan jika diolah. Proses Kegiatan pertama yang kami lakukan pada saat pelatihan adalah memberikan motivasi kepada para penyandang disabilitas bahwasannya penyandang disabilitas adalah anugerah terindah yang diberikan tuhan dan jangan pernah menyerah karena kekurangan tersebut, hal ini dilakukan agar penyandang disabilitas merasa berharga dan mempunyai semangat untuk berusaha menghasilkan kreativitas dibalik keterbasannya. Proses kegiatan yang kedua adalah dengan mengajarkan keterampilan dari plastik bekas menjadi hiasan yang bisa menjadi produk lalu dijual, pada saat pengabdian dilakukan mereka sangat antusias dan semangat untuk mengikuti kegiatan ini. Yang ketiga memberikan pengenalan bagaimana produk dari plastik bekas yang bisa menjadi hiasan dapat dipasarkan melalui e-commerce. Di masa sekarang dengan teknologi yang berkembang semakin pesat dan sebagian besar orang-orang melakukan pekerjaan dengan menggunakan handphone dan sering membuka aplikasi e-commerce, maupun aplikasi sosmed, kami memperkenalkan penggunaan e-commerce untuk promosi agar produk terkenal lebih luas dari pada dengan penjualan tradisional. Promosi maupun penjualan melalui e-commerce dinilai lebih efektif dan efisien serta dapat menghemat biaya dan tenaga. 


\section{Perbedaan Perdagangan Tradisional dengan E-commerce}

Dari hasil pengamatan didapatkan beberapa perbedaan antara perdagangan tradisional dengan e-commerce (Shopee/ Tokopedia), diantaranya:

Tabel 1. Perbedaan perdagangan tradisional dengan e-commerce

\begin{tabular}{|c|c|c|}
\hline $\begin{array}{l}\text { Dasar perbandingan } \\
\text { antara } E \text {-commerce } \\
\text { dengan perdagangan } \\
\text { tradisional }\end{array}$ & E-commerce & Perdagangan Tradisional \\
\hline Definisi & $\begin{array}{l}\text { E-commerce merupakan salah } \\
\text { satu bentuk belanja online } \\
\text { dimana pengguna dapat } \\
\text { membeli barang dan jasa } \\
\text { dari perangkat } \\
\text { elektroniknya seperti laptop, } \\
\text { handphone, tablet. }\end{array}$ & $\begin{array}{l}\text { Perdagangan Tradisional } \\
\text { adalah pendekatan } \\
\text { tradisional untuk membeli } \\
\text { barang dan jasa secara } \\
\text { langsung yang melibatkan } \\
\text { transaksi tatap muka. }\end{array}$ \\
\hline Kegunaan & $\begin{array}{l}\text { Ini digunakan untuk } \\
\text { menghemat waktu dan uang } \\
\text { yang berharga. }\end{array}$ & $\begin{array}{l}\text { Ini kuno dan masih } \\
\text { digunakan di mana jaringan } \\
\text { digital tidak dapat dijangkau. }\end{array}$ \\
\hline Proses & $\begin{array}{l}\text { Lebih mudah digunakan } \\
\text { dan dioperasikan jika } \\
\text { pelanggan memiliki } \\
\text { pengetahuan dasar tentang } \\
\text { gadget digital. }\end{array}$ & $\begin{array}{l}\text { Itu dapat diikuti oleh siapa } \\
\text { pun tanpa memandang } \\
\text { pendidikan atau } \\
\text { pengetahuan. }\end{array}$ \\
\hline Mode & $\begin{array}{l}\text { Ini hanya dalam mode } \\
\text { elektronik atau digital }\end{array}$ & $\begin{array}{l}\text { Bisa dalam bentuk apapun } \\
\text { yang non elektronik atau } \\
\text { manual. }\end{array}$ \\
\hline Waktu & Ini tersedia sepanjang waktu & $\begin{array}{l}\text { Ini tersedia selama waktu } \\
\text { terbatas sebagaimana } \\
\text { ditentukan oleh hukum dan } \\
\text { berdasarkan jenis bisnis. }\end{array}$ \\
\hline Pembayaran & $\begin{array}{l}\text { Memeriksa produk sebelum } \\
\text { membeli tidak } \\
\text { dimungkinkan dalam tipe } \\
\text { ini. }\end{array}$ & $\begin{array}{l}\text { Memeriksa produk sebelum } \\
\text { membeli dimungkinkan } \\
\text { dalam model bisnis } \\
\text { perdagangan tradisional. }\end{array}$ \\
\hline Keterlibatan & $\begin{array}{l}\text { Ini hanya melibatkan } \\
\text { keterlibatan gadget digital } \\
\text { untuk melakukan } \\
\text { pemesanan }\end{array}$ & $\begin{array}{l}\text { Ini melibatkan keterlibatan } \\
\text { langsung dari pembeli dan } \\
\text { penjual }\end{array}$ \\
\hline Bisnis & $\begin{array}{l}\text { Lebih banyak bisnis dapat } \\
\text { dilakukan dengan mudah } \\
\text { tanpa kerumitan }\end{array}$ & $\begin{array}{l}\text { Sulit untuk melakukan lebih } \\
\text { banyak bisnis dalam model } \\
\text { ini }\end{array}$ \\
\hline
\end{tabular}

\section{Kelebihan dan Kendala Pemasaran Produk Melalui E-commerce}

Menurut (Maryama, 2013) Faktor-faktor yang mendasari perusahaan dalam menggunakan e-commerce terdiri dari beberapa faktor ekspektasi perusahaan untuk menerapkan e-commerce: 


\section{JURNAL ABDIMAS BSI}

Jurnal Pengabdian Kepada Masyarakat

1. Mengakses pasar global

2. Mempromosikan produk

3. Bangun merek

4. Lebih dekat dengan pelanggan

5. Membantu komunikasi yang cepat dengan pelanggan

6. Memuaskan pelanggan

Menurut (Sugeng, 2017) proses e-commerce, perusahaan membutuhkan beberapa komponen agar operasional dan aktivitas e-commerce dapat berjalan dengan lancar, sebagai berikut:

1. Kontrol akses dan keamanan, e-commerce harus memberikan rasa nyaman dan kepercayaan serta akses yang aman kepada pihak bersama dalam transaksi $e$ commerce. Kontrol akses dan keamanan perlu dilakukan untuk melindungi $e$ commerce dari berbagai ancaman

2. Membuat profil dan personalisasi. profiling bertujuan untuk manajemen akun dan pembayaran.

3. Manajemen pencarian, perangkat lunak harus memiliki komponen pencarian yang dapat membantu pelanggan untuk menemukan atau menemukan layanan yang mereka inginkan.

4. Content and catalog management Isi e-commerce sebagian besar berupa katalog yang berisi informasi produk atau jasa yang dijual. Lebih lanjut, manajemen konten dan katalog dapat diperluas ke konfigurasi produk yang mendukung layanan mandiri

5. Workflow Management, e-commerce work-flow digunakan untuk membantu karyawan berkolaborasi secara elektronik untuk menyesuaikan garis terdepan masing-masing dengan menggunakan proses kerja saat ini.

6. Notifikasi aktivitas, proses notifikasi aktivitas memegang peranan yang sangat penting dalam sistem e-commerce karena digunakan untuk memantau semua proses e-commerce dan mencatat semua aktivitasnya. Termasuk perubahan harga.

7. Kerjasama perdagangan. Tujuan e-commerce adalah untuk mendukung perjanjian kerjasama dan layanan perdagangan yang dibutuhkan oleh pelanggan dan pemasok lainnya.

8. Proses pembayaran elektronik, Pembayaran elektronik sebagai proses nyata dan penting dalam transaksi e-commerce. Saat ini kebanyakan e-commerce menggunakan proses pembayaran kartu kredit.

Manfaat besar e-commerce untuk penyandang disabilitas adalah salah satunya mempermudah mempromosikan produk dan pemasaran produknya. Selain itu untuk meningkatkan omset penjualan, menambah jumlah pelanggan dari dalam dan luar negeri, memperluas jangkauan bisnis suatu perusahaan, sarana promosi, dan terbukanya usaha baru yang dapat meningkatkan pendapatan perusahaan. Dalam menciptakan perusahaan e-commerce yang sukses dan berkelanjutan, perusahaan perlu mencari cara yang dapat meningkatkan kepuasan pelanggan dan loyalitas pelanggan agar bersedia kembali ke perusahaan, berapa banyak faktor yang dapat mengoptimalkan e-commerce: 


\section{JURNAL ABDIMAS BSI}

Jurnal Pengabdian Kepada Masyarakat

1. Pilihan dan nilai produk yang menarik, kompetitif, serta mampu menjaga dan menjamin kepuasan konsumen setelah membeli produk.

2. Keamanan informasi nasabah yang melakukan transaksi di website dan produk yang dipercaya nasabah

3. Hubungan dan komunikasi.

4. Beriklan melalui web dan email beserta penawaran harga khusus atas produk yang dijual ke pelanggan.

5. Kinerja dan pelayanan, termasuk proses navigasi, proses jual beli, konfirmasi pembayaran dan pengiriman barang lebih cepat.

Dengan menggunakan e-commerce, masyarakat dapat mengubah daftar harga atau melakukan kustomisasi produk atau jasa yang ditawarkan sehingga dapat diinformasikan dengan cepat kepada pelanggan, sesuatu yang biasanya dilakukan dengan waktu yang lama sedangkan menggunakan e-commerce dapat dilakukan dengan cepat. Namun terlebih dahulu kita harus mengetahui konsep pemasaran, artinya kita harus menganalisis pasar, barang atau jasa yang akan dijual di bisnis online. Konsep ini harus dilakukan karena produk atau jasa yang kita jual nantinya dapat memenuhi kebutuhan konsumen.

E-commerce merupakan solusi bagi individu maupun kelompok dalam mengembangkan usahanya. Sebagai penyandang disabilitas juga dipermudah dengan adanya e-commerce untuk berwirausaha. Keterbatasan fisik yang dimiliki tidak menyurutkan semangat dalam mencari uang. Pemanfaatan teknologi yaitu melalui bisnis online adalah langkah tepat bagi mereka yang ingin mendapatkan keuntungan.

Dalam konteks hubungan mitra bisnis, e-commerce dapat membantu mengurangi kemungkinan inefisiensi dalam tawar-menawar produk, menyederhanakan proses bisnis yang mendukung dengan menggabungkan kecepatan dan efisiensi dalam kegiatan bisnis.

Dalam hubungan dengan pelanggan, e-commerce memfasilitasi aktivitas pembelian yang sangat nyaman dan penghematan waktu. Menurut (Herman \& Yakub, 2010) kemunculan e-commerce dapat berdampak pada dunia bisnis, antara lain:

1. Memfasilitasi promosi produk dan layanan secara interaktif dan real-time melalui koneksi internet ke konsumen

2. Layanan pelanggan yang lebih cepat dan memuaskan

3. Menghemat biaya pengiriman informasi dan produk secara signifikan

4. Menciptakan jalur distribusi baru yang dapat menjangkau lebih banyak pelanggan baru baik di dalam maupun luar Indonesia

5. Memfasilitasi aplikasi satu-ke-satu yang lebih efektif atau iklan langsung

6. Menghemat biaya dan waktu dalam menangani pesanan, karena pemesanan elektronik memungkinkan proses yang lebih cepat dan akurat

7. Menghadirkan dunia maya sebagai pelengkap pasar tradisional

8. Membuat saluran distribusi baru yang dapat menjangkau banyak pelanggan 


\section{JURNAL ABDIMAS BSI}

Jurnal Pengabdian Kepada Masyarakat

Dampak positifnya bagi konsumen.

1. Memungkinkan konsumen untuk berbelanja dan bertransaksi selama 24 jam

2. Memungkinkan pelanggan untuk berpartisipasi dalam lelang virtual

3. Memungkinkan pelanggan mendapatkan produk atau jasa dengan harga lebih murah karena pelanggan dapat berbelanja di banyak tempat dengan cepat

4. Menyediakan banyak produk dan pemasok kepada pelanggan

5. Mendorong pelanggan untuk berinteraksi dengan pelanggan lain

E-commerce memiliki banyak dampak positif bagi dunia bisnis namun e-commerce juga berdampak negatif terhadapnya:

a. Pencurian informasi rahasia milik perusahaan atau milik pelanggan, setiap gangguan yang timbul dapat mengungkapkan semua informasi kepada pihak yang tidak berwenang dan mengakibatkan kerugian

b. Kerugian finansial langsung karena penipuan

c. Hilangnya peluang bisnis karena gangguan layanan seperti gangguan jaringan, listrik mati

d. Kehilangan kepercayaan dari pelanggan

Tantangan e-commerce dalam dunia bisnis dalam banyak hal perusahaan dapat bertahan tidak hanya mengandalkan kekuatan produk atau jasanya tetapi juga pada pengiriman yang cepat dan tepat waktu, pelayanan yang baik, jaringan internet yang cepat, desain yang baik dan membuat pelanggan ingin membeli barang. Beberapa faktor menurut (Disa, 2011) antara lain:

1. Menyediakan layanan pembelian yang cepat dan ramah

2. Berikan perhatian khusus seperti memberikan proposal pembelian

3. Memfasilitasi aktivitas perdagangan

4. Memberikan banyak bonus kepada pelanggan

5. Memberikan harga yang kompetitif

Kendala dari e-commerce bagi penyandang disabilitas salah satunya adalah masih kebingungan atau gagap teknologi. Perlu pendampingan dan praktik langsung kepada penyandang disabilitas. Selain itu masih banyaknya pembeli yang masih belum percaya karena khawatir akan terjadi pencurian kartu kredit dan barang yang diinginkan tidak datang atau berbeda dengan yang diinginkan pembeli. Selain itu, perusahaan yang menerapkan e-commerce membutuhkan perawatan yang sangat mahal dan jaringan yang sering mengalami gangguan. Namun, untuk sistem bisnis ke bisnis, tidak ada masalah yang lebih rumit daripada di atas, karena para pengusaha belum memiliki model yang baik untuk menyiapkan e-commerce yang lebih baik. Masalah utamanya adalah ide berbagi informasi bisnis dengan pelanggan dan pemasok yang menjadi strategi utama dalam sistem e-commerce. Kunci pemecahan masalah tersebut adalah dengan menyediakan sistem yang aman dan andal yang dapat menghentikan pemikiran buruk tentang e-commerce, sehingga perusahaan mendapatkan keuntungan dan dapat bersaing dengan perusahaan lain. 


\section{Cara Promosi Produk di E-commerce (Shopee dan Tokopedia)}

Untuk meningkatkan penjualan ada beberapa cara yang bisa dilakukan oleh para penjual, diantaranya:

\section{a. Bergabunglah dengan Flash sale}

Flash sale adalah periode terikat waktu singkat di mana Anda memberikan penawaran yang sangat berharga seperti diskon, bundel produk baru, atau hal lain yang belum ditawarkan kepada pemirsa Anda baru-baru ini.

Sifat kampanye yang terikat waktu, sering dikombinasikan dengan stok produk yang terbatas, menarik pelanggan untuk segera membeli, daripada menunggu. Ini memanfaatkan naluri manusia untuk secara impulsif membeli sesuatu kalau-kalau kita ketinggalan. Penjualan kilat di eCommerce adalah taktik yang sangat bagus untuk menjual stok yang sudah tidak sesuai musim atau lini produk berkinerja buruk yang hanya menghabiskan ruang di ruang penyimpanan Anda.

\section{b. Sampel gratis atau produk berharga rendah}

Salah satu hal tersulit yang harus dilakukan dalam e-commerce adalah membangun kepercayaan dengan calon pelanggan agar mereka memiliki kepercayaan terhadap kualitas produk Anda. Anda dapat mengatasinya dengan menawarkan sampel gratis produk Anda dengan harga pengiriman, atau produk dengan harga sangat rendah di mana Anda tidak membuat margin, agar produk berkualitas Anda sampai ke tangan lebih banyak orang. Taktik ini cenderung bekerja lebih baik ketika orang cenderung membeli salah satu produk Anda dalam jumlah besar, produk tersebut mudah rusak dan perlu diganti, atau Anda memiliki sederet produk kelas atas yang melengkapi produk yang Anda berikan. Gratis.

\section{c. Bundel produk terlaris dengan produk margin tinggi}

Penawaran bundel adalah taktik promosi lama lainnya, dan sangat efektif, untuk toko ritel untuk meningkatkan nilai pesanan rata-rata mereka.

Konsep umumnya adalah Anda mengambil sekelompok kecil produk, mengemasnya sebagai "Bundel", dan kemudian menawarkannya dengan harga kolektif yang lebih murah daripada jika pelanggan membeli masing-masing produk secara individual.

Penawaran bundel terbaik memiliki karakteristik sebagai berikut:

1) Produknya saling melengkapi.

2) Setiap produk individu dalam bundel menarik sebagai pembelian mandiri.

3) Paket ini, tentu saja, lebih murah daripada membeli masing-masing produk secara terpisah.

4) Paket tersebut mencakup setidaknya satu produk bermargin tinggi sehingga Anda dapat memperoleh keuntungan dari harga jual yang diturunkan. 


\section{d. Kupon atau diskon waktu terbatas}

Urgensi adalah taktik pemasaran psikologis yang ampuh untuk toko eCommerce karena ini mempercepat keputusan pembelian pelanggan dan mengurangi kemungkinan mereka meninggalkan situs Anda tanpa membeli.

Cara efektif untuk mendapatkan urgensi adalah dengan menawarkan kupon atau diskon yang hanya tersedia untuk waktu yang terbatas. Anda dapat menjalankan ini sebagai promosi mandiri untuk jangka waktu tertentu, atau sebagai alternatif, Anda dapat menyiapkan kupon kedaluwarsa yang dikirimkan ke prospek atau pelanggan pada waktu-waktu strategis dalam hubungan Anda. Ini mungkin terjadi saat mereka mendaftar ke daftar email Anda, melakukan pembelian pertama, atau jika mereka tidak aktif selama jangka waktu tertentu.

\section{e. Keterlibatan obrolan langsung}

Konsumen saat ini tidak sabar. Mereka ingin produk dikirim dalam hitungan hari atau bahkan jam. Mereka mengharapkan pertanyaan mereka segera dijawab, atau mereka akan membuka situs web berikutnya dan membeli apa yang mereka inginkan dari sana. Mereka dimanjakan dengan pilihan. Anda dapat memenuhi keinginan ini untuk segera bertindak dengan widget obrolan langsung di situs web Anda. Ini tidak hanya menjadi saluran langsung bagi pelanggan yang memiliki pertanyaan, tetapi juga bisa menjadi cara untuk melibatkan browser situs web dan mengubahnya menjadi pembeli.

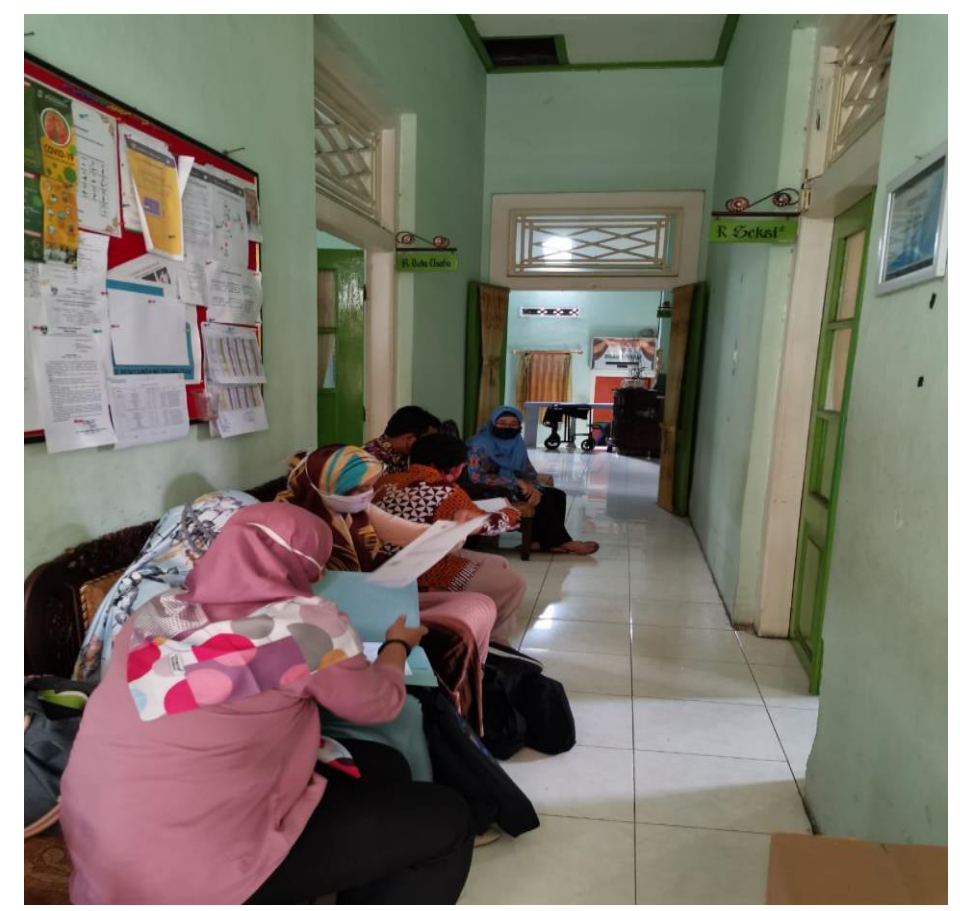

Gambar 1. Rapat koordinasi tim bersama Dinas Sosial Kota Magelang 


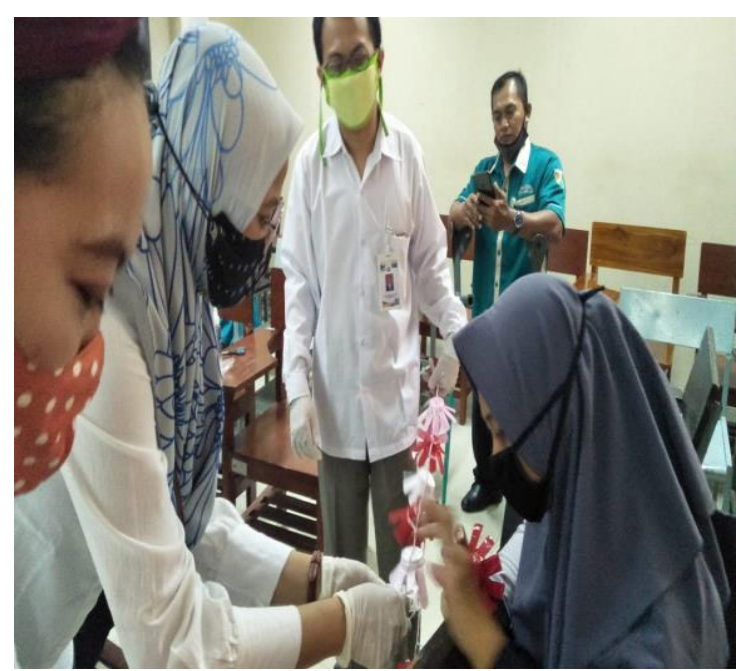

Gambar 2.Pelatihan Pemanfaatan barang plastik bekas menjadi hiasan

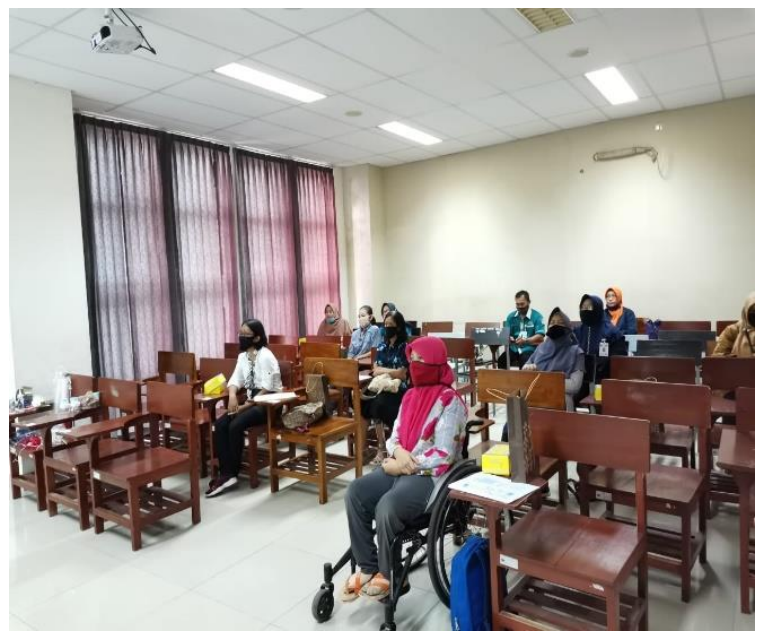

Gambar 3. Pelatihan Pengenalan Penjualan Produk melalui e-commerce

\section{Simpulan dan Rekomendasi}

Pemanfaatan dan pemanfaatan teknologi internet diharapkan dapat memberikan manfaat yang besar bagi para penyandang disabilitas. Sebagai salah satu upaya untuk mengembangkan bisnis, banyak hal yang harus dilakukan salah satunya dengan menerapkan e-commerce. Penyandang disabilitas yang mampu memanfaatkan ecommerce dapat meningkatkan daya saing dan penjualan. E-commerce adalah pemanfaatan teknologi terkini seperti telepon dan internet untuk memudahkan kegiatan jual beli produk, komunikasi dengan pelanggan dan pengusaha lain untuk saling membantu. Dengan memanfaatkan teknologi digital yang seseorang mampu menghasilkan uang tanpa terkendala oleh adanya pandemi yang terjadi saat ini. Selain itu kesimpulan yang diperoleh adalah penyandang disabilitas semakin sadar betapa majunya teknologi internet saat ini dan penyandang disabilitas semakin bersemangat dalam memajukan ekonominya dengan memanfaatkan plastik bekas menjadi hiasan yang dapat dijual. Keterbatasan dalam pelatihan ini hanya sekali karena pandemi covid-19 yang semakin hari pasien makin bertambah dan rentannya kesehatan penyandang disabilitas. 


\section{Penghargaan}

Pengabdian ini di danai oleh LPPM-PMP Universitas Tidar Tahun Anggaran 2020. Yang diketuai oleh Ayunda Putri Nilasari, S.Pd, M.Si dengan anggota Yulida Army Nurcahya, SE., M.Acc dan Risma Wira Bharata, SE., M.Sc beserta mahasiswa Rizky Puspita

\section{Daftar Pustaka}

Ahmed Z, Su L, Rafique K, K. S. Z. \& J. S. (2017). A study on the factors affecting consumer buying behavior towards online shopping in Pakistan. Journal of Asian Business Strategy, 7(2), 44.

Apenko, S. (2017). Human Resource Management of Innovative Projects in the Context of Business Strategy. Strategic Management, 22(1), 3-6.

Bernal-Merino, M. (2018). Quantum identity and the enhancement of communication. Journal of Brand Strategy, 6(4), 380-391.

Bruni A, Cassia F, \& M. F. (2017). Marketing performance measurement in hotels, travel agencies and tour operators: a study of current practices. Current Issues in Tourism. Current Issues in Tourism, 20(4), 339-345.

Disa, S. (2011). E-Commerce Sebagai Solusi Pemasaran Bagi Usaha Mikro Kecil Dan Menengah (UMKM). Jurnal Teknologi Informasi Dan Komunikasi, 1(2). https://doi.org/http:/ / dx.doi.org/10.35585/inspir.v1i2.9

Herman, H., \& Yakub, Y. (2010). KAJIAN TENTANG PERKEMBANGAN EBUSINESS TERHADAP PRAKTIK BISNIS. CommIT (Communication and Information Technology) Journal, 4(2), 86-89. https:/ / doi.org/https:/ / doi.org/10.21512/commit.v4i2.540

Kotler dan Keller. (2009). Manajemen Pemasaran (1st ed.). Jakarta: Erlangga.

Lee J \& Kim Y. (2018). "A Newcomer" versus "First Mover": Retail Location Strategy for Differentiation. The Professional Geographer, 70(1), 22-33.

Maryama, S. (2013). Penerapan e-Commercedalam Meningkatkan Daya Saing Usaha. Jurnal Liquidity, 2(1), 73-79.

Pallud J, \& S. D. W. (2014). Effective website design for experience-influenced environments: The case of high culture museums. Information $\mathcal{E}$ Management, 51(3), 359-373.

Patrutiu-Baltes, L. (2016). Inbound Marketing-the most important digital marketing strategy. Bulletin of the Transilvania University of Brasov Series V Economic Sciences, 9(2), 61. https://doi.org/10.7150/ijbs.17030

Presiden Republik Indonesia. (2016). UU No.8 tahun 2016. Jakarta: Sekretariat Negara. Sugeng. (2017). E-COMMERCE SEBAGAI PENDUKUNG PEMASARAN. JSI (Jurnal Sistem Informasi) Universitas Suryadarma, 4(1), 143-156. https://doi.org/https:// doi.org/10.35968/jsi.v4i1.81

Sugiyono, P. (2016). Metode Penelitian (Pendekatan Kuantitatif, Kualitatif, dan RED). Bandung: Alfabeta.

Tiago M T P M B \& Veríssimo J M C. (2014). Digital marketing and social media: Why Bother? Business Horizons, 57(6), 703-708. 